\title{
The percentage of affected fragments in needle biopsy in the assessment of pathological staging of prostate cancer
}

\author{
o percentual de fragmentos acometidos na biópsia de agulha na \\ avaliação do estadiamento patológico do câncer da próstata
}

Rógerson Tenorio de Andrade ${ }^{1}$; Roberto Gonçalves de Lucena²; Catarina de Moraes Braga';

Vilma Maria da Silva ${ }^{4}$; Misael Wanderley Santos Jr.; Nicodemos Teles de Pontes Filho ${ }^{6}$

\begin{abstract}
Introduction: Prostate cancer has high prevalence and mortality among men. Some of the findings on prostate biopsy may be related to the prognosis of the disease. Objective: To evaluate the association between the percentage of fragments affected by cancer in the prostate biopsy and the pathological staging in the surgical specimen. Materials and methods: Selected 159 patients underwent radical prostatectomy (RP) between 2003 and 2009. Data was collected on age, digital rectal exam, prostate-specific antigen (PSA), Gleason score, number of biopsy fragments, number of fragments affected by tumor, and tumor extension in the surgical specimen. Statistical analysis with Student's $t$-test, chi-squared test, and multiple logistic regression evaluated the association of percentage of affected fragments (PAF) with tumor extension and its predictive value. Results: The patients mean age and PSA were respectively 64 years and $8.5 \mathrm{ng} / \mathrm{ml}$. Histopathologic evaluation of surgical specimens revealed $20.8 \%$ of patients with extraprostatic disease, $8.2 \%$ with seminal vesicle invasion and $35.8 \%$ with positive margins. We found that patients with extraprostatic disease, positive surgical margins, and seminal vesicle invasion had a higher mean PAF. PAF was divided into three groups: less than 34\%,34\% to 50\%, and greater than 50\%, and the higher the PFA, the larger the increase in pathological changes. Conclusion: PAF in biopsy is a simple and practical parameter, which should be used as a predictor of pathological stage in RP specimen.
\end{abstract}

Key words: prostatic neoplasm; needle biopsy; pathology; neoplasm staging.

\section{INTRODUCTION}

Prostate cancer represents a third of all diagnosed neoplasms, being the second cause of death from malignant diseases in the United States of America (USA) ${ }^{(12,13,18)}$. In Brazil, an incidence of $52.4 / 100,000$ inhabitants was estimated in $2010^{(11)}$; it is the fourth cause of death from neoplasms, what corresponds to $6 \%$ of total deaths from cancer ${ }^{(15)}$.
The introduction of prostate-specific antigen (PSA) as a screening test associated with public prevention policies has stimulated the conduction of systematic transrectal ultrasoundguided prostate biopsy, with a resulting increased diagnosis of clinically localized disease ${ }^{(8)}$.

Radical prostatectomy (RP) is considered the treatment of choice for localized prostate cancer, but the finding of extraprostatic dissemination in the surgical specimen has a negative impact on patients' survival ${ }^{(24)}$.

First submission on 26/06/13; last submission on 19/07/13; accepted for publication on 23/07/13; published on 20/10/13

1. Master's degree in Pathology from Universidade Federal de Pernambuco (UFPE); urologist; volunteer doctor at Hospital das Clínicas (HC) of UFPE.

2. Doctorate in Surgery from UFPE; associate professor at the Department of Surgery of UFPE.

3. Graduating student of Medicine at UFPE.

4. Medical Residency at HC-UFPE; substitute professor of the Department of Surgery at UFPE.

5. Doctorate in Surgery from UFPE; urologist at HC-UFPE.

6. Doctorate in Nutrition from UFPE; full professor of Anatomical Pathology at UFPE. 
Preoperative parameters have been used in the selection of patients for surgery. Partin et al. ${ }^{(17)}$ reported that preoperative PSA level, biopsy Gleason score and clinical stage are independent predictors of the final pathological stage. Based on these data, they developed a preoperative nomogram for risk of extraprostatic extension, seminal vesicle invasion and lymph node metastasis. Using the same parameters, D'Amico et al. ${ }^{(4)}$ defined three risk groups concerning biochemical recurrence after RP.

More recently, some studies have shown that measurement of the amount of cancer in prostate biopsies has a predictive value for adverse pathology and risk of biochemical failure ${ }^{(2,5,7,8,19)}$. The objective of this work is to evaluate the association between the percentage of positive prostate biopsy fragments and the pathological staging of the surgical specimen.

\section{MATERIALS AND METHODS}

A retrospective analysis of clinical and pathological data was conducted on all patients subjected to RP in the Urology Department of Hospital das Clínicas (HC) from Universidade Federal de Pernambuco (UFPE), from January 2003 to August 2009.

Data were collected on patients' age, digital rectal exam, preoperative PSA, clinical staging, Gleason score, number of biopsy fragments, percentage of fragments affected by tumor, presence of positive margins, seminal vesicle invasion and extraprostatic tumor extension.

Patients who had received adjuvant radiotherapy or hormone therapy, those with stage T1a or T1b, and those with incomplete data in the medical records were excluded from the study. Age was measured by the number of completed years of age at surgery date. The highest serum PSA level before the prostate biopsy was considered the preoperative PSA level. Gleason score was used to assess the histological differentiation of the tumor, and the clinical and pathologic staging was determined according to the Classification of Malignant Tumours (TNM) 1997 - American Joint Committee Cancer (AJCC) $)^{(18)}$.

The fragments of prostate biopsy and surgical specimens were completely processed and referred to a pathologist specialized in the field of uro-oncology. Extracapsular extension was defined as invasion of the adipose tissue or the periprostatic neurovascular bundle, classified as pT3a according to TNM system; organ-confined disease, as stage pT2. Seminal vesicle invasion was defined as infiltration of tumor cells into the wall of the seminal vesicle, being classified as pT3b. Positive surgical margin was defined as presence of tumor cells at the inked surface of the specimen.

The percentage of affected fragments (PAF) in prostate biopsy was calculated by dividing the number of positive fragments by the total number of biopsy fragments, and multiplying the result by 100 .

In the statistical analysis, we used Student's $t$-test to study averages, chi-squared test to compare proportions among groups, and multiple logistic regression to analyse the predictive value of PAF. Statistical significance was defined as $p<0.05$, and the statistical calculations were performed using software BioStat version 5.0 for Windows.

This study follows the principles of Resolution $n^{\circ} 196$, from October 10, 1996, of the National Health Council, on research involving human beings. It was submitted to and approved by the ethics committee of the Center for Health Sciences of UFPE.

\section{RESULTS}

One hundred ninety-two patients were submitted to RP between January 2003 and August 2009. Nine patients were excluded for having received neoadjuvant hormone therapy; one for being classified, according to clinical stage, as T1a; and 23 for incomplete data in the medical records. Table 1 shows the clinical and pathological characteristics of the 159 selected cases.

Table 2 compared the mean PAF in the groups of patients with intra- and extraprostatic disease, presence or absence of positive surgical margins ( $\mathrm{M}+$ and $\mathrm{M}-$ ), and presence or absence of seminal vesicle invasion (SV+ and SV-). In the three groups, the difference among means was significant.

In Table 3, the PAF was stratified in three groups: lower than $34 \%, 34 \%-50 \%$, and higher than $50 \%$. In each group the incidence of extraprostatic extension was studied, as well as seminal vesicle invasion and positive surgical margins. In the group of patients with PAF lower than $34 \%$, we found $7 \%$ extraprostatic disease, $3 \% \mathrm{SV}+$ and $14 \% \mathrm{M}+$. An increase in the identified pathological alterations accompanied the increase in PAF, and this difference was also significant.

By multiple logistic regression analysis, the PAF presented significant predictive value in relation to the pathological findings in the surgical specimen (Table 4). 


\begin{tabular}{|c|c|c|c|}
\hline \multicolumn{4}{|c|}{$\begin{array}{l}\text { TABLE } 1 \text { - Clinical and pathological } \\
\text { characteristics of the } 159 \text { patients }\end{array}$} \\
\hline & Mean & $\mathrm{SD}^{*}$ & Interval \\
\hline Age (years) & 64.16 & 5.99 & $45-76$ \\
\hline PSA (ng/ml) & 8.47 & 4.95 & $1.33-28.1$ \\
\hline $\begin{array}{l}\mathrm{N}^{0} \text { fragments obtained } \\
\text { per biopsy }\end{array}$ & 12.35 & 3.84 & $6-28$ \\
\hline $\mathrm{PAF}$ & 38.37 & 23.39 & $6.66-100$ \\
\hline \multicolumn{4}{|l|}{ Clinical staging } \\
\hline T1c & $71(44.7 \%)$ & - & - \\
\hline $\mathrm{T} 2 \mathrm{a}$ & $74(46.5 \%)$ & - & - \\
\hline $\mathrm{T} 2 \mathrm{~b}$ & $14(7.8 \%)$ & - & - \\
\hline \multicolumn{4}{|l|}{ Biopsy Gleason } \\
\hline$<7$ & $99(62.3 \%)$ & - & - \\
\hline 7 & $48(30.2 \%)$ & - & - \\
\hline$>7$ & $12(7.5 \%)$ & - & - \\
\hline Extraprostatic disease & $33(20.8 \%)$ & - & - \\
\hline Seminal vesicle invasion & $13(8.2 \%)$ & - & - \\
\hline Positive surgical margins & $57(35.8 \%)$ & - & - \\
\hline \multicolumn{4}{|c|}{$\begin{array}{l}\text { *SD: standard deviation; PSA: prostate-specific antigen; PAF: percentage of } \\
\text { affected fragments. }\end{array}$} \\
\hline \multicolumn{4}{|c|}{$\begin{array}{l}\text { TABLE } 2 \text { - Assessment of mean percentage of affected fragments } \\
\text { and pathological findings in the surgical specimen }\end{array}$} \\
\hline & Mean PAF & & $p^{*}$ \\
\hline EPD & $52.2 \%$ & & $<0.0001$ \\
\hline IPD & $33.9 \%$ & & - \\
\hline $\mathrm{SV}+$ & $60.4 \%$ & & 0.0002 \\
\hline SV- & $36.4 \%$ & & \\
\hline $\mathrm{M}+$ & $53.8 \%$ & & $<0.000$ \\
\hline M- & $29.7 \%$ & & - \\
\hline
\end{tabular}

PAF: percentage of affected fragments; EPD: extraprostatic disease; IPD: intraprostatic disease; SV+: presence of seminal vesicle invasion; SV-: absence of seminal vesicle invasion; $M+$ : presence of positive surgical margins; $M-:$ absence of positive surgical margins.

"Student's t-test.

TABLE 3 - Incidence of pathological findings in the different stratification levels of the percentage of affected fragments

\begin{tabular}{ccccc}
\hline PAF & $\mathrm{N}^{0}$ & EPD (\%) & SV+ (\%) & M+ (\%) \\
\hline$<34$ & 88 & $6(7)$ & $2(3)$ & $12(14)$ \\
$34-50$ & 29 & $9(31)$ & $5(17)$ & $19(65)$ \\
$>50$ & 42 & $18(43)$ & $6(14)$ & $26(62)$ \\
& 159 & $p<0.0001$ & $* p<0.0093$ & $p<0.0001$ \\
\hline
\end{tabular}

PAF: percentage of affected fragments; EPD: extraprostatic disease; $S V+$ : presence of seminal vesicle invasion; $M+$ : presence of positive surgical margins.

"Chi-squared test.

\begin{tabular}{cccc}
\hline $\begin{array}{l}\text { TABLE 4 - Multiple logistic regression analysis of the percentage of } \\
\text { affected fragments in the prediction of pathological findings }\end{array}$ \\
\hline & OR & $p$ & CI 95\% \\
\hline EPD & 1.04 & $<0.0001$ & $1.02-1.06$ \\
SV+ & 1.04 & 0.0067 & $1.01-1.06$ \\
M+ & 1.06 & $<0.0001$ & $1.04-1.08$ \\
\hline
\end{tabular}

OR: odds ratio; CI: confidence interval; EPD: extraprostatic disease; SV+: presence of seminal vesicle invasion; $M+$ : presence of positive surgical margins.

\section{DISCUSSION}

In this article, the study population presented similar characteristics to those of other works in literature, in relation to both age group and mean PSA, and pathological characteristics (Table 1$)^{(1)}$, being the mean number of fragments per biopsy greater than in other works.

The main factor associated with the biological behavior of prostate tumor is tumor volume in the RP specimen ${ }^{(22)}$. Several authors have investigated clinical and pathological preoperative parameters of prostate cancer patients for the development of algorithms to predict tumor stage in the RP specimen ${ }^{(17)}$. Among the reasons for this interest are the good results with other treatment options for these patients, such as external radiotherapy and brachytherapy; the choice for the surgical technique, such as the nerve-sparing or seminal vesicle-sparing surgery ${ }^{(8,10)}$; the presence of comorbidities that exclude surgery as a treatment option $^{(21,23)}$; and the identification of patients at high risk of tumor recurrence that could benefit from neoadjuvant or adjuvant therapy ${ }^{(14)}$.

The amount of cancer in the prostate biopsy has been measured by several methods: total length of cancer in the biopsy in cubic millimeters, total percentage of cancer in the biopsy, number of affected fragments, PAF and maximum length or percentage of cancer in a single fragment ${ }^{(1,2,19)}$.

PAF in the prostate biopsy has been accepted as the most easily reproducible parameter, since it takes little time from the pathologist and may standardize the different biopsy strategies ${ }^{(1,6,25,26}$; in several articles it has been considered an excellent predictor of poor results after $\mathrm{RP}^{(4,7,9,16,21)}$. In a recent study, Quintal et al. ${ }^{(19)}$ evaluated these several methods to predict extraprostatic disease and identified that the maximum length or percentage of cancer in a single fragment was not significant: the total percentage of cancer in the biopsy was the method with the strongest predictive value.

The importance of PAF in the prediction of organ-confined disease was studied by Sebo et al. ${ }^{(21)}$. When cancer is confined 
to prostate, the average of positive fragments is $35 \%$, while in individuals with extraprostatic disease the average rises to $55 \%$. In our work, we found similar values, respectively 33.9\% and $52.2 \%$. Lotan et al. ${ }^{(14)}$ reported that the average PAF in patients with positive seminal vesicles was $50 \%$, compared to $22.2 \%$ in those with negative seminal vesicles; we found, respectively, $60.4 \%$ and $36.4 \%$.

This difference was significantly higher in patients with extraprostatic disease and positive seminal vesicles (pT3) $)^{(14,21,26)}$ in comparison with patients with organ-confined disease (pT2), revealing a strong association between tumor involvement on biopsy and pathologic staging.

D'Amico et al. ${ }^{(5)}$ observed that the percentage of positive fragments in biopsy is an important parameter to predict intraprostatic disease, showing that, when less that $34 \%$ of fragments are affected, $79 \%$ of patients have disease confined to the gland, and when the number of affected fragments is higher than $50 \%$, only $43 \%$ have the confined disease. In our study we observed that when there are less than $34 \%$ of affected fragments, the incidence of organ-confined disease was $93 \%$, and this value is reduced to $57 \%$ in individuals with more than $50 \%$ of the fragments affected. Dall'Oglio et al. ${ }^{(6)}$ revealed that seminal vesicle involvement was $6.2 \%$ in patients with PAF inferior to $25 \%$, and $31.7 \%$ in those with PAF higher than $75 \%$. We found 3\% for PFA lower than 34\%, and 14\% for PFA higher than $50 \%$.

Sebo et al. ${ }^{(21)}$ were the first to confirm the predictive value of PAF and affirmed that in patients undergoing sextant biopsies, the presence of more than one affected fragment (that is, $\mathrm{PAF}>17 \%$ ) has a 3 - to 5 -fold increased risk. Calvete et al. ${ }^{(3)}$ affirmed that a PAF $>75 \%$ is considered of poor prognosis for the presence of extraprostatic disease, and that these patients must receive a combined type of treatment, because surgery only would be little effective. Ojea et al. ${ }^{(16)}$ classified patients in low and high risk according to the classification by D'Amico et al. ${ }^{(4)}$ and stratified PAF in these groups, identifying that among the low-risk patients there were those who presented a high PAF, and these had a higher risk of extraprostatic disease. They also concluded that PAF is useful for individuals with clinically localized disease.

Sakai et al. ${ }^{(20)}$ studied 120 patients who underwent sextant prostate biopsy and reported that the best cut-off value of PAF for prediction of extraprostatic disease was 33\%. They suggested that its incorporation to existing nomograms could improve their predictive accuracy. In Table 3, we find significant difference between the group of patients with less than $34 \%$ of fragments affected and the groups of patients with 34\%-50\% and above $50 \%$. Specifically in relation to seminal vesicle involvement and positive surgical margins, there is no difference between groups 34\%-50\% and above $50 \%$. This suggests that the best cut-off point to predict extraprostatic extension is $33 \%$.

Freedland et al. ${ }^{(7)}$ reviewed the records of 1,094 patients submitted to RP from SouthEastern Aerosol Research and Characterization (SEARCH) database and concluded that PAF in prostate biopsy is a significant predictor of adverse pathology and biochemical failure. They also suggested a risk-stratification approach for recurrence, based on PAF: low risk (up to 34\%), moderate risk (35\%-50\%), and high risk (> 50\%).

Partin et al. ${ }^{\left({ }^{(1)}\right)}$ were pioneers in developing nomograms to predict tumor staging, using PSA, prostate biopsy Gleason score and clinical stage. Gancarczyk et al. ${ }^{(8)}$ studied 1,527 patients and described a nomogram that estimated the probability of extraprostatic disease, involvement of seminal vesicles and lymph nodes. In this nomogram, they added PAF and removed clinical staging from the system, claiming that clinical staging has lost importance lately, as more than $60 \%$ of patients currently diagnosed with prostate cancer have stage T1c. Furthermore, they studied the sensitivity and specificity of the nomogram in comparison to isolated prognostic factors, and suggested its superiority, but highlighted the necessity of further studies for its validation

Prostate cancer, over the last decades, has been considered an epidemic; its incidence and mortality are increasing in our country due to the increased life expectancy and improved diagnostic methods, as well as public prevention policies. The study of preoperative parameters to predict tumor pathological staging allows a more effective treatment, and a resulting increase in the chances of cure. In this context, this article aimed at confirming PAF in prostate biopsy as a tool to be considered in the assessment of prostate cancer.

\section{CONCLUSION}

Based on the obtained results of data from 159 patients included in this study, and according to other studies reported in the literature, we concluded that PAF in biopsy is an important predictive factor of the pathological stage in the specimen of RP. It must be used in daily practice, along with other already established parameters, to provide better prognostic and therapeutic management to patients. 


\section{RESUMO}

Introdução: O câncer de próstata é uma das neoplasias de maior prevalência e mortalidade entre os homens. Alguns dos achados na biópsia prostática podem estar relacionados com o prognóstico da doença. Objetivo: Avaliar a associação do percentual de fragmentos acometidos (PFA) por câncer na biópsia prostática com estadiamento patológico na peça cirúrgica. Materiais e métodos: Estudo retrospectivo de 159 pacientes submetidos à prostatectomia radical (PR) entre 2003 e 2009. Foram coletados dados sobre idade, exame retal digital, antígeno prostático específico (PSA), escore de Gleason, número de fragmentos da biópsia, número de fragmentos acometidos e extensão tumoral na peça operatória. A análise estatística com os testes t de Student, qui-quadrado e regressão logística múltipla avaliou a associação do PFA com a extensão tumoral e o seu valor preditivo. Resultados: A média de idade e PSA dos pacientes foram, respectivamente, de 64 anos e $8,5 \mathrm{ng} / \mathrm{ml}$. A avaliação histopatológica revelou 20,8\% de pacientes com doença extraprostática; 8,2\% com invasão das vesículas seminais e 35,8\% com margens comprometidas. Encontramos, nos pacientes com doença extraprostática, margens cirúrgicas comprometidas e invasão das vesículas seminais, uma média do PFA significativamente superior. O PFA foi estratificado em três grupos: menor que 34\%; 34\% a 50\% e maior que 50\%; quanto maior o PFA, maior o aumento nas alterações patológicas. Conclusão: O PFA na biópsia é parâmetro simples e prático que pode ser utilizado como preditor da extensão tumoral no espécime da prostatectomia radical.

Unitermos: neoplasia prostática; biópsia por agulba; patologia; estadiamento de neoplasia.

\section{REFERENCES}

1. ANDRADE, R. T. et al.0 percentual de fragmentos acometidos na biópsia como preditor da extensão do câncer de próstata: revisão sistemática. Rev Bras Canc, v. 53, n. 3, p. 359-66, 2010.

2. ANTUNES, A. A. et al. Preoperative determination of prostate cancer tumor volume: analysis through biopsy fragments. Int Braz J Urol, v. 33, n. 4, p. 477-85, 2007.

3. CALVETE, A. C. et al. Extraprostatic disease prediction in patients with carcinoma of the prostate: role of PSA, prostatic biopsy fragments percentage and Gleason score. Rev Assoc Med Bras, v. 49, n. 3, p. 250-4, 2003.

4. D’AMICO, A. V. et al. Biochemical outcome after radical prostatectomy, external beam radiation therapy, or interstitial radiation therapy for clinically localized prostate cancer. JAMA, v. 280, p. 969-73, 1998.

5. D'AMICO, A. V. et al. Clinical utility of the percentage of positive prostate biopsies in defining biochemical outcomes after radical prostatectomy for patients with clinical localized prostate cancer. J Clin Oncol, v. 18, p. 1164-72, 2000.

6. DALL'OGLIO, M. F. et al. Prediction of pathological stage in prostate cancer through the percentage of involved fragments upon biopsy. Int Braz J Urol, v. 31, n. 5, p. 445-51, 2005.

7. FREEDLAND, S. J. et al. Percent of prostate needle biopsy cores with cancer is significant independent predictor of prostate specific antigen recurrence following radical prostatectomy: results SEARCH database. J Urol, v. 169, n. 6, p. 2136-41, 2003.

8. GANCARCZYK, K. J. et al. Using the percentage of biopsy cores positive for cancer, pretreatment PSA, and highest biopsy Gleason sum to predict pathologic stage after radical prostatectomy: the Center for Prostate Disease Research nomograms. Urology, v. 61, n. 3, p. 589-95, 2003.
9. GROSSKLAUS, D. J. et al. Percent of cancer in the biopsy set predicts pathological findings after prostatectomy. J Urol, v. 167, n. 5, p. 2032-6, 2002.

10. GUZZO, T. J. et al. Preoperative parameters, including percent positive biopsy, in predicting seminal vesicle involvement in patients with prostate cancer.J Urol, v. 175, n. 2, p. 518-21, 2006.

11. INSTITUTO NACIONAL DO CÂNCER - INCA (BRASIL). Incidência do câncer no Brasil - Estimativa 2010. Available at: <http://www.inca.gov. br/estimativa/2010>. Accessed on: 10 Sep. 2010.

12. JEMAL, A. et al. American Cancer Society: Cancer statistics 2010. CA Cancer J Clin, v. 60, n. 5, p. 277-300, 2010.

13. KLEIN, E. A.; PLATZ, E. A.; THOMPSON, I. M. Epidemiology, etiology, and preventions of prostate cancer. In: WEIN, A. J. Campbell-Walsh Urology. 9. ed. Pennsylvania: Saunders, 2007. v. 3, Cap. 90; p. 2854-72.

14. LOTAN, Y. et al. The percent of biopsy cores positive for cancer is a predictor of advanced pathological stage and poor clinical outcomes in patients treated with radical prostatectomy.J Urol, v. 171, n. 6, p. 2209-14, 2004.

15. MINISTÉRIO DA SAÚDE (BRASIL). Secretaria Nacional de Assistência à Saúde. Instituto Nacional do Câncer. Coordenação de Vigilância Conprev. Câncer de próstata: consenso. Rio de Janeiro, INCA, 2002, 15 p. 16. OJEA, C. A. et al. Correlation of the anatomo-pathological staging of radical prostatectomy specimens with the amount of cancer in the preoperative sextant biopsy. Actas Urol Esp, v. 27, n. 6, p. 428-37, 2003.

17. PARTIN, A. W. et al. Contemporary update of prostate cancer staging nomograms (Partin tables) for the new millennium. Urology, v. 58, n. 6 , p. 843-8, 2001.

18. PRESTI, J. C. Neoplasms of prostate gland. In: TANAGHO, E. A. Smith's general urology. 6. ed. San Francisco: McGraw-Hill Companies, 2004. Cap. 22; p. 367-385. 
19. QUINTAL, M. M. et al. Various morphometric measurements of cancer extent on needle prostatic biopsies: which is predictive of pathologic stage and biochemical recurrence following radical prostatectomy? Int Urol Nephrol, v. 43, n. 3, p. 697-705, 2011.

20. SAKAI, I. et al. Significance of the percentage of prostate needle biopsy cores with cancer as a predictor of disease extension in radical prostatectomy specimens in Japanese men. Int Urol Nephrol, v. 37, n. 2 p. 305-10, 2005.

21. SEBO, T. J. et al. The percent of cores positive for cancer in prostate needle biopsy specimens is strongly predictive of tumor stage and volume at radical prostatectomy. J Urol, v. 163, n. 1, p. 174-8, 2000

22. STAMEY, T. A. et al. Biological determinants of cancer progression in men with prostate cancer.JAMA, v. 281, n. 15, p.1395-1400, 1999.
23. SUEKANE, S. et al. Percentages of positive cores, cancer length and Gleason grade $4 / 5$ cancer in systematic sextant biopsy are all predictive of adverse pathology and biochemical failure after RP. Int J Urol, v. 14, n. 8, p. $713-8,2007$

24. VILLAMÓN-FORT, R. et al. Percentage of cancer in prostate biopsies as prognostic factor for staging and postoperative biochemical failure after radical prostatectomy. Urol Inter, v. 78, p. 328-33, 2007.

25. WINKLER, M. H. et al. The total percentage of biopsy cores with cancer improves the prediction of pathological stage after radical prostatectomy. BJU Int, v. 94, n. 6, p. 812-5, 2004.

26. ZAM, N. A. et al. Correlation between prostate needle biopsies and radical prostatectomy specimens: can we predict pathological outcome? Pathology, v. 40, n. 6, p. 586-91, 2008. 